\title{
Growth Responses of Calendula (Calendula officinalis L.) to Temperature Regimes and Different Soil Types
}

\author{
Yasser I. El-Nashar ${ }^{1}$
}

\begin{abstract}
Temperature stress is the major environmental regime that affects agricultural production worldwide, especially in arid and semi-arid regions. Arid and semi-arid regions are characterized by highly variable environmental conditions were temperature goes extremely low to extremely high and affects the performance, physiology and biochemistry of the plants. This research investigated the effect of temperature regimes on sowing seeds of Calendula officinalis $L$. at $(1,15$ September and 1,15 October, 2013 and 2014) grown in different soil types (clay, loamy, sand and mix between them). Significant increases in vegetative growth characters were observed for plants cultivated in sandy soil compared to those cultivated in clay loamy or mixed soils. The best result was obtained with 15 September treatment sandy soil plants. This result included higher branches number and leaf area, higher shoot fresh and dry weights, as well as higher number of flowers. Physiological traits include transpiration rates, stomatal conductance, intercellular $\mathrm{CO}_{2}$ concentration and sample cell $\mathrm{H}_{2} \mathrm{O}$, were highly significant in first October planting date with clay loamy soil type in both seasons. Environmental regimes and different soil type's showed clear effects on the biochemical contents (total soluble protein, $\mathrm{H}_{2} \mathrm{O}_{2}$ and catalase activity fractions of the leaves) of three week old seedlings. It is concluded that sowing in September in sandy soil is recommended for Calendula production in arid and semi-arid regions.
\end{abstract}

Keywords: Arid and semi-arid environment, Biochemical contents, Calendula, Gas exchange, Growth, Water potential.

\section{INTRODUCTION}

Calendula (Calendula officinalis L.) (pot marigold, English marigold) belongs to the Asteraceae (Compositae) family; it is an annual plant with bright or yellow orange daisy-like flowers which are used for ornamental, medicinal or culinary purposes (Cromack and Smith, 1988).

Selected Calendula chemotypes growing in vitro or in soil, flowers of the cadinolchemotype, are very important in European and western Asian folk medicines and are used to treat inflammatory conditions (Masayuki et al., 2001). Distinct subspecies of C.officinalis have been reported from various countries
(Nicoletta et al., 2003), i.e. Herbaria, Mecsek, Adamoand Golden Dragon (Bakô et al., 2002). Calendulacan be used as a colorant species because it primarily contains two classes of pigments, the carotenoids and flavonoids, which can be used as orange and yellow natural colors, respectively. Natural colors are gaining considerable attention since several synthetic colorants have given rise to toxic, carcinogenic and allergic effects (Lea, 1988).

Environmental constraints are major factors limiting crop productivity in several regions of the world (Shah and Paulsen, 2003). Abiotic stresses such as drought and high temperature frequently limit the growth and productivity of major crop species including Calendula. In additional concern is global climate change, with the expected increase in global temperatures, intensification of drought, changed distribution of precipitation in arid and semiarid areas (Wigley and Raper, 2001), and the combination among those factors with growth stage, leading to reductions in productivity (Bai et al., 2004). It was found that a combination of heat stress and drought had a significantly greater harmful effect on the growth and productivity of crops compared with a stress applied alone (Savin and Nicolas, 1996;Wang and Huang, 2004). For example, during heat stress, plants open their stomata to cool their leaves by transpiration. Nevertheless, if heat stress is combined with drought, the plants have to keep their stomata closed to reduce water loss, so the leaf temperature leftovers high (Rizhsky et al., 2002). Such combined stresses often have the largest negative effects on flowers yield.

The objective of this study is to investigate the impact of seasonal dynamics of temperature on an important medicinal plant Calendula grown under different soil types. A number of growth parameters were determined under temperature regimes, including vegetative growth and flower yield components. The gas-exchange measurements, water potential and enzymatic activities were also under consideration.

\section{MATERIALS AND METHODS}

\section{Field location and climate}

${ }^{1}$ Plant Production Department, College of Food and Agriculture Sciences, King Saud University. P.O. Box 2460 Riyadh 11451, King Saudi Arabia. ${ }^{2}$ Ornamental Plants and Landscape Gardening Research Department, Al-Montaza, Horticultural Research Institute, A.R.C. Giza, Egypt.

E-mail: yelnashar@ksu.edu.sa

Received March 30, 2016, Accepted 4 May, 2016 
The field study was carried out in the College of Food and Agricultural Sciences of the King Saud University, Riyadh, Saudi Arabia, 24⒋'12.66”N and $46^{\circ} 37^{\prime} 13.32^{\prime \prime} \mathrm{E}$. The climate of the region was arid with very little precipitation through the year, except some flash rains in March and April. In winter, the temperatures were mild with some few winds and sand storms. Monthly averages of the temperature, solar radiation, relative humidity, evapotranspiration, rainfall, and wind speed are shown in Table (1).

\section{Plant materials}

Calendula seeds (Calendula officinalis L. cv. Calypso Yellow) provided by Sakata's Reliable Seeds Company (USA), were sown on different planting dates; September 1, 15 and October 1, 15, 2013 for the first season and 2014 for the second season. Seedlings were planted in plastic trays. Thirty-day-old seedlings (healthy and uniform in size) were transplanted into 15 $\mathrm{cm}$ diameter plastic pots (one seedling pot $^{-1}$ ) containing different soil types (sand, clay loamy and mix between them 1:1, v:v) as shown in Table (2).

\section{Experimental design}

The experiment layout was a spilt plot system in random complete block design (RCBD), with three replicates for the first and second seasons (Steel and Torrie, 1986). Every replicate contained 12 treatments for the first season [four times sown September (1 (T1), 15 (T2) and October 1(T3), 15 (T4) x three different soil types]. The main plots were devoted for the four times sowing date sand the sub-plots included the three different soil types. Fifty seeds were used for each treatment in each replicate; the total number of seeds used in the experiment was 1800 seeds season ${ }^{-1}$.

\section{Experimental data}

Seed germination percentage after four weeks from sowing was recorded. Plants were grown until flowers maturity and harvested (about 180 days) from planting. At harvest, the plant height, diameter of flower and root length was measured using a tape measure and calipers. Leaf area was measured using a leaf area meter (LI-Cor, Lincoln, NE, USA). Number of branches, leaves and flowers plant ${ }^{-1}$ were counted. Flowering date (days from seed sowing) in each treatment was determined. Shoot and root fresh and dry masses (FM and DM) were also estimated. DM was recorded after fresh shoots and roots were oven-dried at $70^{\circ} \mathrm{C}$ for $48 \mathrm{~h}$.

Leaf chlorophyll and anthocyanin contents were determined using a hand-held chlorophyll content meter (CCM-200 and ACM-200, Optic science, USA, respectively). The chlorophyll and anthocyanin contents determination were measured on the fifth youngest leaves.

Table 1. Meteorological data at Riyadh, Saudi Arabia during the two growing seasons

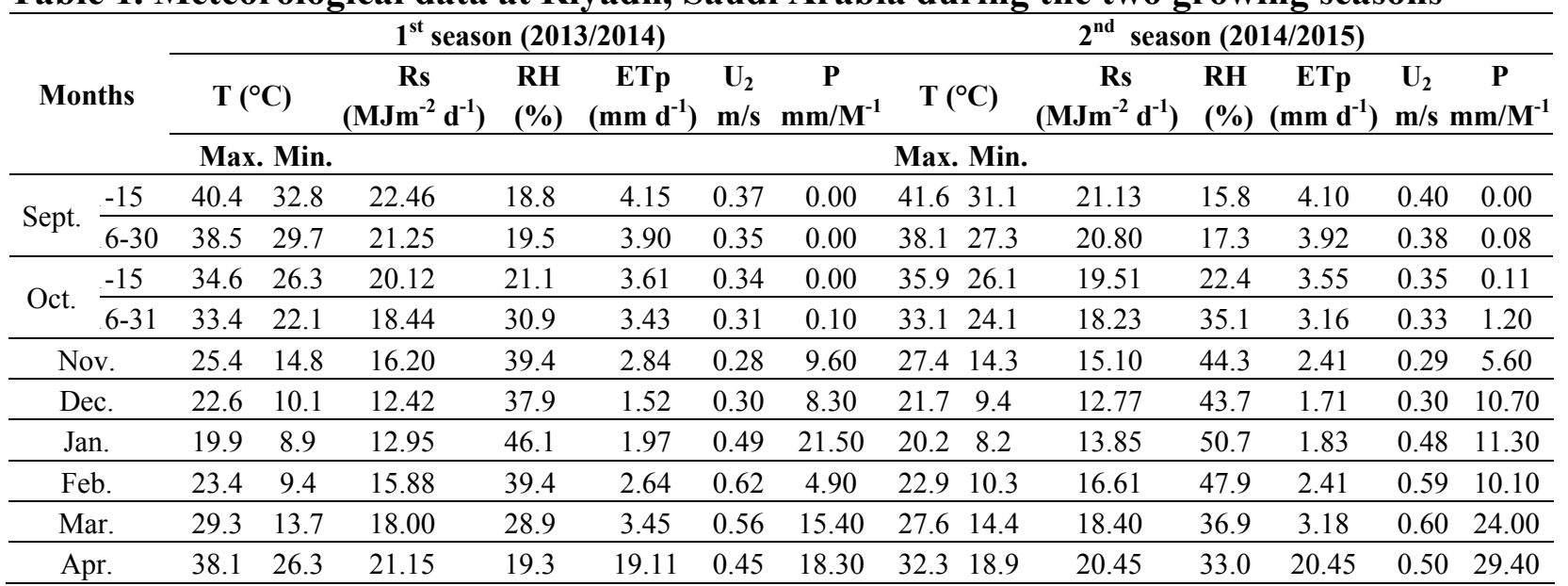

Monthly average. T: temperature; Rs: solar radiation; RH: relative humidity; ETp: potential evapotranspiration; $\mathrm{U}_{2}$ : wind speed; P: precipitation. Data from the Presidency of Meteorology \& Environment Protection, Riyadh, Saudi Arabia.

Table 2. Physical and chemical properties of the soil

\begin{tabular}{|c|c|c|c|c|c|c|c|c|c|c|c|c|c|c|c|}
\hline \multirow[b]{2}{*}{$\begin{array}{l}\text { soil } \\
\text { type }\end{array}$} & \multicolumn{15}{|c|}{ Soluble cations and anions (mequiv./l) } \\
\hline & $\begin{array}{c}\text { sand } \\
\%\end{array}$ & $\begin{array}{c}\text { Silt } \\
\%\end{array}$ & $\begin{array}{c}\text { clay } \\
\%\end{array}$ & SAR & pH & $\begin{array}{c}\mathrm{EC} \\
\left(\mathrm{ds} / \mathbf{m}^{-1}\right)\end{array}$ & $\mathbf{N a}+$ & Mg++ & $\mathbf{C a}++$ & $\mathbf{K}+1$ & $\mathrm{HCO}_{3}{ }^{1}$ & $\mathrm{CaCo}_{3}$ & $\mathrm{Cl}^{1-}$ & $\mathrm{SO}_{4}{ }^{2-}$ & $\begin{array}{c}\mathbf{P} \\
\text { (av.P) }\end{array}$ \\
\hline Sand & 93 & 5 & 2 & 1.41 & 8.23 & 0.96 & 1.13 & 0.29 & 1.03 & 0.05 & 0.25 & 21.38 & 1.25 & 1.04 & 8.81 \\
\hline $\begin{array}{l}\text { Clay } \\
\text { loamy }\end{array}$ & 38 & 32 & 30 & 3.15 & 8.39 & 049 & 5.67 & 1.46 & 5.13 & 0.16 & 1.23 & 2.94 & 5.98 & 4.88 & 10.6 \\
\hline
\end{tabular}




\section{Physiological measurements}

\subsection{Gas exchange and leaf water potential} measurements

Leaf photosynthesis rate $(P n)$, transpiration rate $(\mathrm{E})$, stomata conductance $\left(g_{s}\right)$, intercellular $\mathrm{CO}_{2}$ concentration $\left(\mathrm{C}_{\mathrm{i}}\right)$ and sample cell $\mathrm{H}_{2} \mathrm{O}\left(\mathrm{S}_{-} \mathrm{H}_{2} \mathrm{O}\right)$ were measured on the flag leaf at anthesis using the portable LI-6400 photosynthesis system (Li-Cor, Lincoln, USA) with the following settings: flow rate $500 \mu \mathrm{mol} \mathrm{s}{ }^{-1}$, leaf/block temperature $20{ }^{\circ} \mathrm{C}$, photosynthetically active radiation (PAR) $1000 \mu \mathrm{mol} \mathrm{m} \mathrm{s}^{-1}$ and ambient $\mathrm{CO}_{2}$ concentration at $400 \mathrm{mg} \mathrm{kg}^{-1} \quad$ (ppm). Four measurements were taken per leaf of all 3 replicates at 15 sec. intervals after the $\mathrm{CO}_{2} / \mathrm{H}_{2} \mathrm{O}$ parameters became relatively stable. The leaf water potential was measured on the leaf at a thesis using the portable PSYPRO water potential system with a pressure chamber (Wescor, Inc., Utah., USA).

\subsection{Biochemical contents}

\subsubsection{Total soluble protein content}

The total protein content was determined according to Lowry et al. (1951) by taking 20 seedling $+25 \mathrm{ml}$ of Tris-Hcl pH 7.6 from each treatment. Plant tissue $(0.5$ gm) + small amount of solution were placed in mortar and crushed till no tissues appear. The mixture was centrifuged at $5000 \mathrm{rpm}$ under freezing for five minutes, and then transferred to keep it under freezing to be used.

\subsubsection{Catalase activity}

Briefly, the reaction solution $(3 \mathrm{~mL})$ for catalase enzyme was comprised of $50 \mathrm{mM}$ phosphate buffer $(\mathrm{pH}$ 7.0), $15 \mathrm{mM} \mathrm{H} 2 \mathrm{O} 2$, and $50 \mathrm{~L}$ enzyme extracts. Reaction was initiated by the addition of $\mathrm{H} 2 \mathrm{O} 2$ to the reaction solution. The catalase activity was determined by following the decomposition of $\mathrm{H} 2 \mathrm{O} 2$ and measuring the absorbance decrease at $240 \mathrm{~nm}$ for $1 \mathrm{~min}$ (Cakmak et al.,1993). The Catalase activity was expressed as $\mu \mathrm{kat} \mathrm{mg}^{-1}$ protein $\mathrm{min}^{-1}$.

\subsubsection{Hydrogen peroxide concentration}

Fresh leaves $(0.1 \mathrm{~g})$ were homogenized in $5 \mathrm{~mL}$ of $0.1 \%$ trichloroacetic acid (TCA). After centrifugation at $12,000 \mathrm{rpm}$ for $15 \mathrm{~min}$, the supernatant $(0.5 \mathrm{~mL})$ was then mixed with $0.5 \mathrm{~mL}$ of phosphate buffer $(\mathrm{pH} 7)$ and $1 \mathrm{~mL}$ of $1 \mathrm{MKI}$. After incubation, the absorbance was taken at $390 \mathrm{~nm}$. The content of $\mathrm{H} 2 \mathrm{O} 2$ was determined using a calibration curve constructed using a series (1$50 \mu \mathrm{M}$ ) of analytic grade $\mathrm{H} 2 \mathrm{O} 2$ (Velikova et al., 2000).

\section{RESULTS}

\section{Effect of temperature regimes}

It is evident from the results that Calendula plants, sown in four different times in Riyadh region, exhibited a diverse pattern of growth, physiological and biochemical attributes. Germination, leaf number, leaf area, shoot and root fresh and dry masses, and flowers yield component (flowering date, flower diameter and flower number) were affected by temperature regimes treatments (T1-T4). Temperature treatment (1 September) gave the highest values of germination on both seasons (Table 3).Plants sown in 15 September in both seasons exhibited highest values for plant height $(16.79$ and $18.24 \mathrm{~cm})$ respectively, whereas the significant reduction in plant height was recorded in 1 September $(13.82$ and $14.30 \mathrm{~cm})$ which was the least value among the four times in the both seasons. However, the plants collected in 15 September and 15 October showed at par values for plant height. Large leaf area was significantly reduced in plants, but the reduction in leaf area due to the growth delay times from T2 to T4 (Table 3).

The increases in treatments from $\mathrm{T} 1$ to $\mathrm{T} 4$ led to delay flowering date and decrease flower number (Table 3). Temperature significantly reduced $(p<0.05)$ the flowering date in plants under both seasons. The increases in flowering date with decrease temperature led to delay flowering date. However, a significant reduction in most flower traits occurred only when sown on 15 Oct. Continuous late in agriculture significantly reduced flower components. Generally, as with some vegetative growth traits, $\mathrm{T} 2$ treatment gave higher flower number plant ${ }^{-1}$.

\section{Response to different soil types}

According to the results presented in table (3), increases were recorded with respect to germination, plant height and flower number per plant traits with sand soil type compared with other soil types. Leaf area was affected by clay loamy soil treatment. However, the highest value of flowering date per plant was found at mix soil treatment.

\section{Interaction effect between temperature and different soil types}

\subsection{Plant growth characters}

The results indicate that the temperature regimes treatments affected significantly Calendula development. Increasing germination percentage was in 1 September with sand, mix than clay loamy soil type. Significant differences were found in most plant growth traits, except for root length, chlorophyll and anthocyanin contents (Tables 4 and 5). Generally, 15 September under clay loamy soil type showed higher plant height, larger leaf area and heavier root fresh and dry masses. 


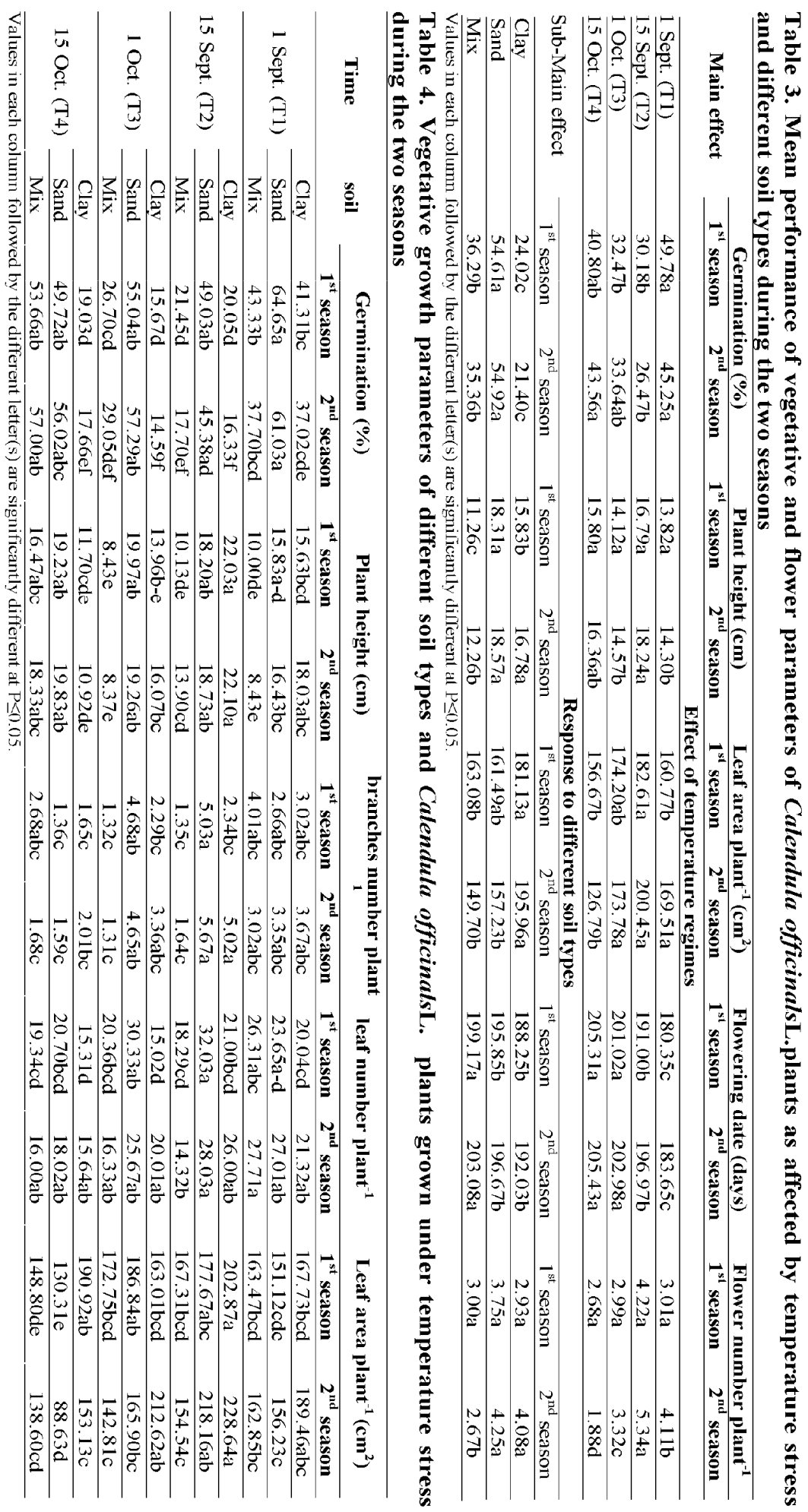


But the same treatment (T2) under sandy soil type showed higher branch number, leave number, fresh and dry masses plant ${ }^{-1}$ traits.

\subsection{Flower characters}

The clay loamy dependency value for flower diameter of Calendula plants was significantly higher under T1 followed by $\mathrm{T} 2$ treatments, but the $\mathrm{T} 2$ with sand soil type apparent increasing flower number of plant $^{-1}$ (Table 6). On the other hand, mix soil type under T2 (15 September) led to delay flowering date compared with all other treatments.

\subsection{Measurement gas exchanges and leaf water potential}

High temperature significantly affected all leaf gas exchange parameters $\left(P n, \mathrm{E}, g_{s}, \mathrm{C}_{\mathrm{i}}\right.$ and $\left.\mathrm{S}_{-} \mathrm{H}_{2} \mathrm{O}\right)$ (Fig.1). The effects of temperature on leaf gas exchange were only observed under the different soil types. However, leaf photosynthesis rate showed conflicting in growth stage (Fig. 1A). Stomata conductance, intercellular $\mathrm{CO}_{2}$ concentration, transpiration rate and sample cell $\mathrm{H}_{2} \mathrm{O}$ increased with treatment of clay loamy soil type in 1 October (Fig. 1B, C, D and E). On the other hand, $g_{s}$ E and $\mathrm{S} \mathrm{H}_{2} \mathrm{O}$ were decreased with decrease temperature and planting date in clay loamy soil type, while they were showed decrease with all the treatments uses mix soil type.

Leaf water potential at morning $\left(\Psi_{1}\right)$ had significantly different values of $-2.86,-2.63$ and $-2.63 \mathrm{MPa}$ in the first season, but values of -3.09 , -2.75 and $-2.01 \mathrm{MPa}$ in the second season for the sand, clay loamy and mix, respectively. The results indicate that interaction effect water potential between the temperature regimes treatments and different soil types significantly affected water potential of Calendula plants. The leaf water potential $\left(\Psi_{1}\right)$ also decreased in sand soil plants at 15 September (Fig. 1F).

\subsection{Biochemical contents}

Data in Figure 2A showed that Calendula plants cultivated in the mix soil type under all treatments had the lowest mean value for total soluble protein, while the highest mean for total soluble protein were detected at September for clay loamy than sand soil types. The comparison between temperatures, data indicated that 1 September had the highest average total soluble protein content.

Data presented in Figure 2B, growing conditions significantly affected the catalase activity enzyme in leaves. Plants collected from sandy soil type in 15 September showed more catalase activity enzyme, but in the low concentrations with late sown seeds. The minimum catalase activity was observed in the leaves of plants grown in 15 October treatment. Changes in environmental conditions significantly affected $\mathrm{H}_{2} \mathrm{O}_{2}$ concentration in all plants (Figure 2C). Nonetheless, clay loamy had more $\mathrm{H}_{2} \mathrm{O}_{2}$ concentration followed by sand and mix soil types under different growing conditions. Clay loamy soil caused greater $\mathrm{H}_{2} \mathrm{O}_{2}$ accumulation in the Calendula at15 September when compared with all temperature regimes in both seasons.

\section{DISCUSSION}

Temperature is an important determinant of morphology, physiology and biochemistry of plants. In this research, we studied growth, morphological, physiological and biochemical attributes of an important medicinal plant Calendula in response to varying temperature conditions of arid and semi-arid land. The plants investigated in September in both seasons with higher temperature (38.5- 29.7 and $38.1-27.3^{\circ} \mathrm{C}$ ) respectively, showed optimum growth (branch number, leaf number, leaf area, shoot and root fresh and dry masses, flower diameter and flower number) whereas the same parameters showed a significant decrease in October. Prakash et al. (2011) observed an increase in morphological characteristics of Plantago plants in suitable environmental conditions and a decrease beyond a certain limit. Sudden and extreme decrease in temperature is accompanied with more stressful conditions which affect the growth and development of plant species. Growth patterns of Calendula plants, fresh and dry mass accumulation were studied as they indicate primary productivity in response to temperature regimes (Smith, 2007). Temperature not only acts as an important limiting factor for enzymatic activities and metabolism of plants, but also regulates cell division, translocation of food and photosynthesis. A temperature of $30^{\circ} \mathrm{C}$ is optimal for most biochemical processes (Devlin and Witham, 1986) in plants. The raise growth characteristic in the studied plants at higher temperature can also be explained on the basis of the fact that plants grown in September are exposed to greater irradiance, large diurnal fluctuations of temperature, reduced partial pressure of gases, increased rate of transpiration due to high wind velocity, limited water and nutrient supply and a narrow time window for growth and development of plants (Streb et al., 1998).

Calendula plants grown in clay loamy soil significantly enhanced some growth parameters more than those of plants grown in sand and mix soil. The difference between the three soils in growth parameters (leaf area, flower diameter, fresh and dry root masses) may be attributed to the ability of clay soil to support the plants by the favorable water and available macroand micro nutrients more than sand and mix soil types (AbouHussien et al., 2010). 


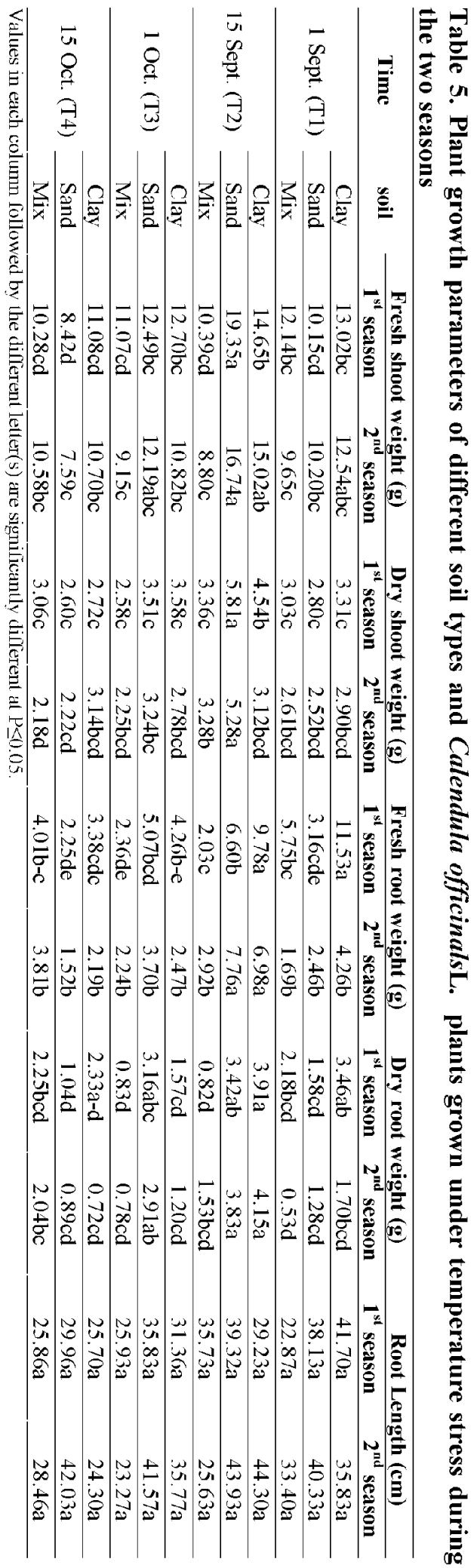




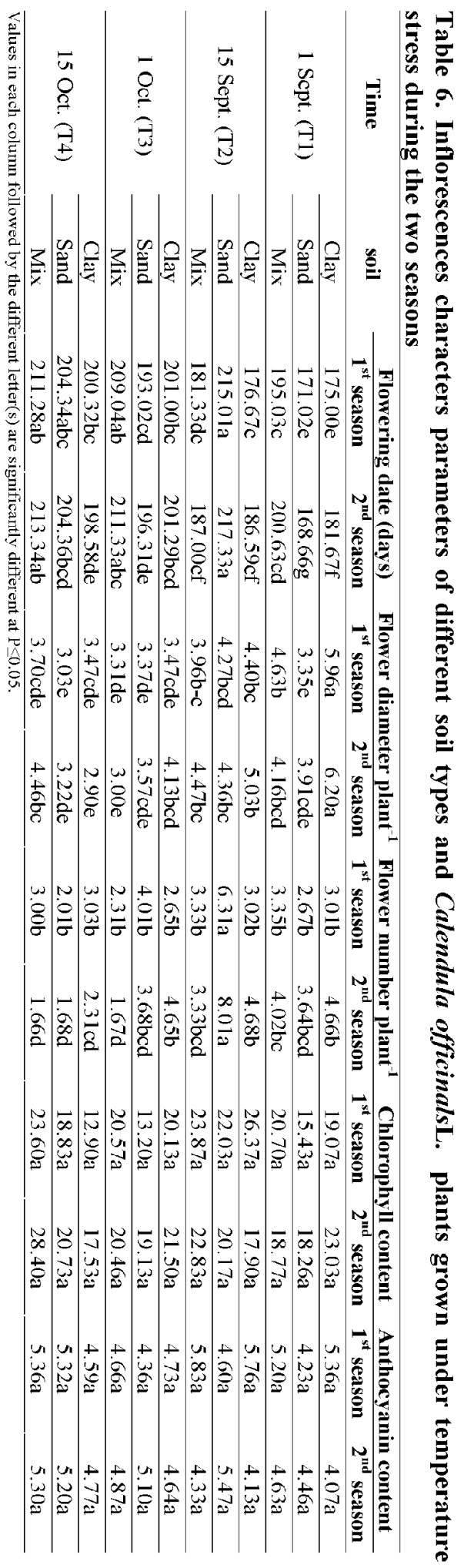



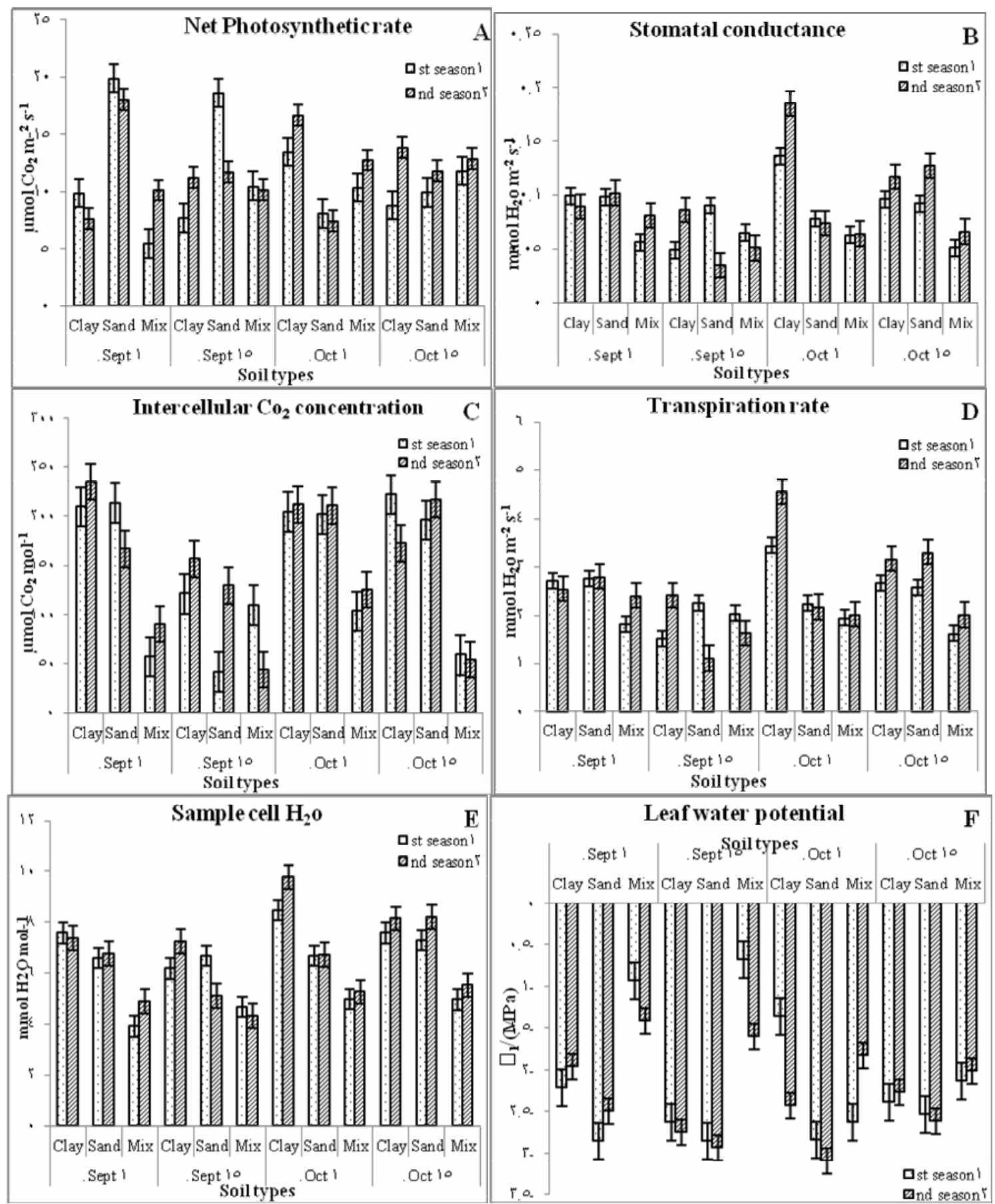

Clay Sand Mix Clay Sand Mix Clay Sand Mix Clay Sand Mix

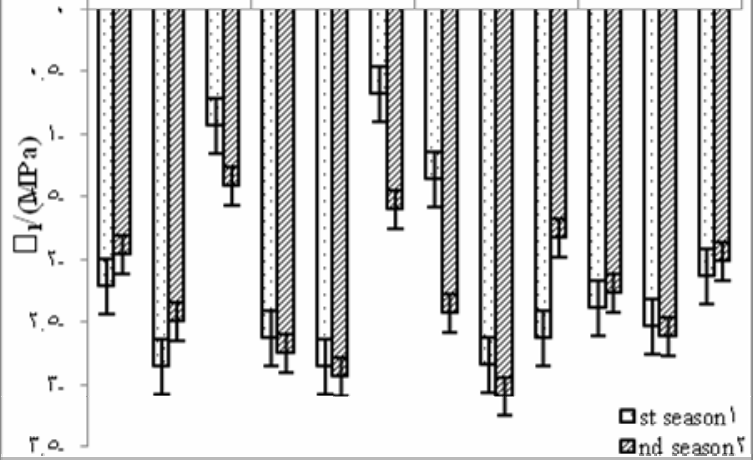

Figure 1. Photosynthetic rate (A), Stomatal conductance (B), Intercellular $\mathrm{CO}_{2}$ concentration (C), Transpiration rate (D), Sample cell $\mathrm{H}_{2} \mathrm{O}(\mathrm{E})$, and Leaf water potential (F) in parameters of different times September 1, 15 and October 1, 15, Calendula plants grown under different soil types, respectively 


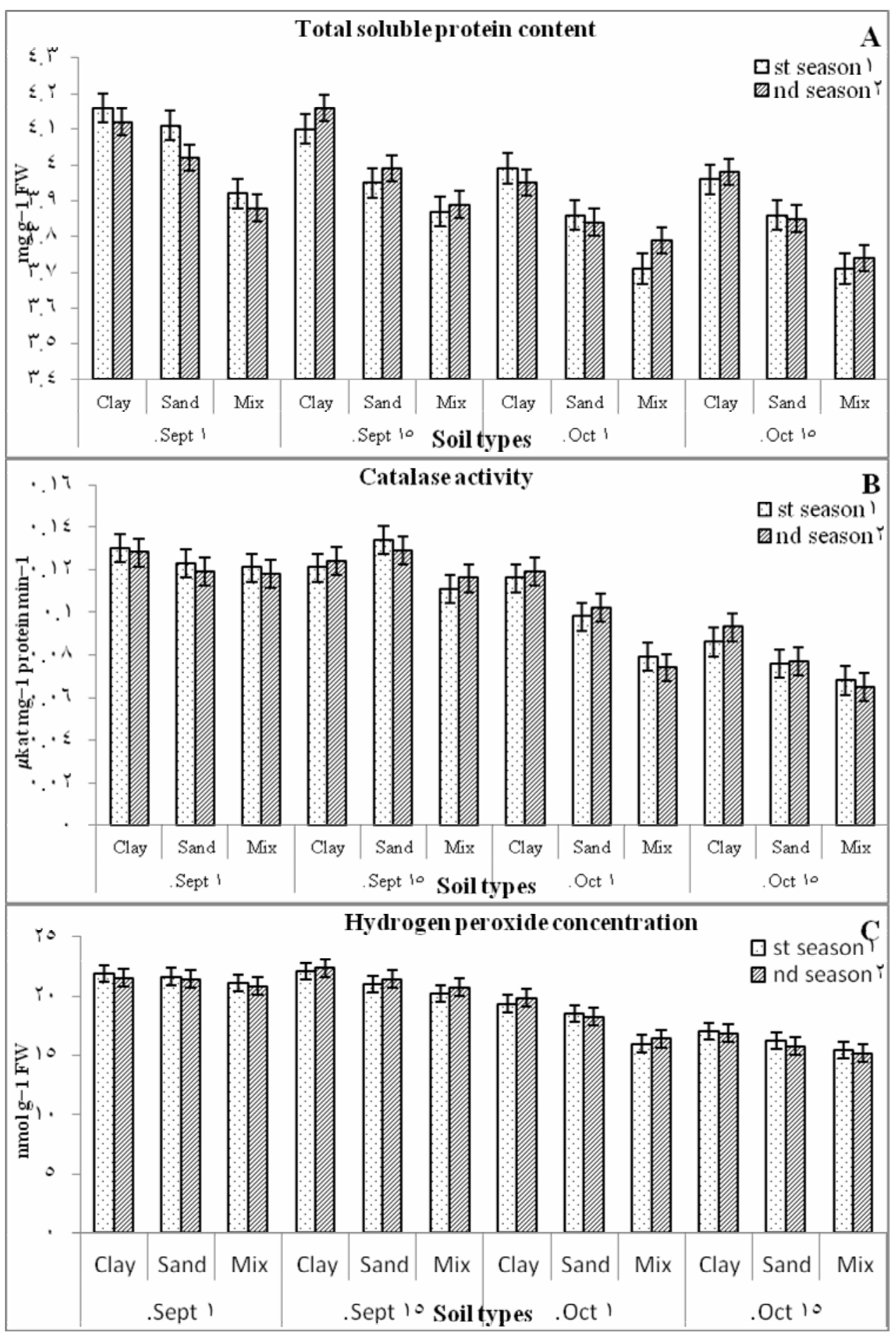

Figure 2. A. total soluble protein, B: catalase enzyme activity and $C$ : Hydrogen peroxide concentration of Calendula as affected by temperature regime (1, 15 September and 1, 15 October) and different soil types of during 2013/2014 - 2014/2015 seasons 
The difference in the mean values of growth parameters of the two seasons may be attributed to varying climatic factors (temperature, relative humidity, etc...) and soil conditions. Similar results were mentioned by Muller and Brandes (1997), Singh et al. (2002) and Baraldi et al. (2008) on Artemisia plants.

Temperature is one environmental factor that profoundly influences plant growth and development. Two common ornamental annual crops, salvia (Salvia splendens) and marigold (Tagetes patula L.), were grown in glass greenhouses under a mean DLI of 5 to $25 \mathrm{~mol} \cdot \mathrm{m}^{-2} \cdot \mathrm{d}^{-1}$ at temperatures from 14 to $27^{\circ} \mathrm{C}$. The rate of development to flowering of salvia and marigold was primarily influenced by the mean air temperature. For example, time from seedling transplant to flowering of salvia decreased from 42 days to 24 days as temperature increased from 15 to $25^{\circ} \mathrm{C}$. Flower number and plant dry mass on the date of first flowering generally decreased with increasing temperature in both species (Lee and Runkle, 2007).

Data presented in Table 4 and 5 indicated that, plants growing in the sand soil, showed a positive increase in same growth parameters comparing to those growing in clay loamy and mix soils, these differences may be attributable to ecotype, climatic conditions, and stress conditions of the sand soils, cultural practices or a combination of these factors. These results confirmed the preceding works of Kumar et al. (2004).

High temperature regimes are known to decrease photosynthesis and productivity of Calendula by different mechanisms. In the present study, the stomata closed when plants were stressed for moisture at moderate or high temperature, which resulted in considerable decline in photosynthesis and transpiration rates (Fig.1). Under different soil type's conditions, high temperature stress decreased the leaf stomatal conductance of all treatments. Overall, the combined effects of different soil types and reduce temperature resulted in higher decline of the different gas exchange parameters. Decline in stomatal conductance was accompanied by corresponding reductions in transpiration and photosynthesis rates, indicating that although stomatal closure conserved water, it also reduced assimilate production. However, both transpiration rate and stomatal conductance declined more than the photosynthesis with mix soil type increased under humidity and high temperature conditions (Anyia and Herzog, 2004).

Concerning physiological and biochemical parameter, Catalase enzyme activity recorded higher value in plant species grown in September and it was lower in plants investigated in October. Catalase is the enzymes which catalyzes the reversible hydration of $\mathrm{CO}_{2}$ and kept its constant supply to rubisco resulted in an optimum rate of photosynthesis and thus more dry material accumulation. Therefore, increased Catalase enzyme activity might have been one of the reasons for improved growth performance of plants at optimum temperature in September. It was also informed that while transpiration rates increased with lower atmospheric pressure at higher temperature, the agreeing increase in $\mathrm{CO}_{2}$ uptake was relatively higher than expected (Gale, 1973), thus there is a possibility of greater non-stomatal capability for $\mathrm{CO}_{2}$ uptake in plants at higher temperature (Li et al., 1993).

Any change in climatic condition results in enhanced intensity of solar ultraviolet radiation, seasonal and daily variations in temperature (Larcher, 1988) results in accumulation of chemically active molecules and free radicals in plant cells causes alterations in metabolic processes (Asada, 1999). To cope with such detrimental conditions, plants are fortified with a system of antioxidant enzymes, which inhibit free radical processes (Keniya et al., 1993). It is shown that under extreme conditions the protective mechanism of antioxidant system is activated. The higher is the antioxidant activity; the extra resistant is the species toward the stressor.

An extreme increase and decrease in temperature causes generation of several detrimental effects and set the plant sunder stress leading to the generation of reactive oxygen species. However, to cope with such stressful conditions, plants are equipped with antioxidant enzymes such as catalase activity enzyme and $\mathrm{H}_{2} \mathrm{O}_{2}$. These enzymes prevent or alleviate the damage caused by reactive oxygen species and set the plants to perform normally even under stressful conditions. The results exhibit that catalase activity enzyme and $\mathrm{H}_{2} \mathrm{O}_{2}$ show a parallel increase in the activities with increasing temperature giving highest values (Vaidyanathan et al., 2003). Thus, increased antioxidant enzyme activities protected the plants from stressful environment which is reflected in terms of improved growth and dry mass and total soluble protein accumulation and catalase activity enzyme in the plants grown in September. On the other hand, plants grown in October showed a decline in antioxidant enzyme activities and physiological, enhanced growth and biochemical parameters including protein accumulation. The inhibition in the activities of antioxidant enzymes during optimum temperature was recorded by Wang et al. (2009). Asthir, 2015 mentioned that the group of proteins called heat shock proteins are synthesized following stress and their synthesis is regulated by transcription factors. Under high temperature, reactive 
oxygen species are often induced and can cause damage to lipids, proteins, and nucleic acids. To scavenge the reactive oxygen species and maintain cell membrane stability, synthesis of antioxidants, osmolytes, and heat shock proteins is of a vital importance.

Any changes in climatic conditions affect growth and development processes in plants as they are depend on many factors, including retention time, season, temperature, relative humidity, wind, soil properties, $\mathrm{pH}$, diversity of species, nutrients availability, hydraulic regimes, plant harvesting and light intensity etc...(Khan and Ansari, 2005; Lu et al., 2010; Abdelmajeed et al., 2013).

\section{CONCLUSION}

This study indicated that environmental factors such as temperature and different soil types affect both growth, morphological, physiological and biochemical. Based on the results of this research it is recommended that during September with sand soil the environmental conditions are best suitable for growth and development use of Calendula officinalis L. So this interaction can be adopted for optimum growth under arid and semi-arid land conditions.

\section{REFERENCES}

Abdelmajeed, N.A., E.N. Danial and H.S. Ayad. 2013. The effect of environmental stress on qualitative and quantitative essential oil of aromatic and medicinal plants. Arch. Sci. 66 (4), 100-120.

AbouHussien, E.A., M.M. EL-Shinnawi, M.A. Abo El-Fadl and M.A. EL-Fishey. 2010. Growth of Corn plants cultivated in differently manured arid soils and irrigated with various water qualities. Menufiya J . Agric. Res., 29 (1), 335-353.

Anyia, A.O. and H. Herzog. 2004. Water-use efficiency, leaf area and leaf gas exchange of cowpeas undermid-season drought. Euro. J. Agro. 20, 327-339.

Asada, K. 1999. The water-water cycle in chloroplasts: scavenging of active oxygens and dissipation of excess photons. Plant Mol. Biol. 50, 601-639.

Asthir, B. 2015. Mechanisms of heat tolerance in crop plants.Biolo. Plant. 59 (4), 620-628.

Bai, Y., X. Han, J. Wu, Z. Z. Chen and L.H. Li. 2004. Ecosystem stability and compensatory effects in the Inner Mongolia grassland. Nature. 431, 181-184.

Bako, E., J. Deli and G. Toth. 2002. HPLC study on the carotenoid composition of Calendula products. J. Biochem. Biophys. Methods. 53, 241-250.

Baraldi, R., B. Isacchi, S. Predieri, G. Marconi, F.F. Vincieri and A.R.Bilia. 2008. Distribution of Artemisinin and bioactive flavonoids from Artemisia annuaL. during plant growth. Bioch. Sys. Eco.36,340-348.

Cakmak, I., D. Strbac and H. Marschner. 1993. Activities of hydrogen peroxide-scavenging enzymes in germinating wheat seeds. J. Exp. Bot. 44(1), 127-132.
Cromack, H. and J. Smith. 1988. Calendula officinalisproduction potential and crop agronomy in southern Eng. Ind. Crops Prod. 7, 223-229.

Devlin, R.M. and F.H. Witham. 1986. Plant Physiology, 4th Ed. CBS Publishers, New Delhi, India, 558.

Gale, J. 1973. Experimental evidence for the effect of barometric pressure on photosynthesis and transpiration. Ecol. Cons. 5, 289-29.

Keniya, M.V., A.I. Lukash and E.P. Gus'kov. 1993. UspekhiSovremennoyBiologii 113(4), 456-470.

Khan, F.A. and A.A. Ansari. 2005. Eutrophication: an ecological vision. Bot. Rev. 71, 449-482.

Kumar, S., S.K. Gupta, P. Singh, P.M. Bajpai, M.M. Gupta. 2004. High yields of Artemisinin by multi-harvest of Artemisia annuacrops. Ind. Cro. Pro. 19(1): 77-90.

Larcher, W. 1988. Ekologiyavysokogorii. Tbilisi. 51-59.

Lea, A.G.H. 1988. HPLC in Food Analysis. Academic Press, London, p. 277.

Lee, A.M. and E.S. Runkle. 2007. Modeling the effects of temperature and photosynthetic daily light integral on growth and flowering of Salvia splendens and Tagetespatula.J. Amer. Sos. Hort. Sci. 132, 283-288.

Li, J.Y., T.M. Qulee, R. Raba, R.G. Amundson, R.L. Last. 1993. Arabidopsis flavonoid mutants are hypersensitive to UVB irradiation. Plant Cell. 5, 171-179.

Lowry, O.H., N.J. Rosebrugh, A.L. Farr, J. Randall. 1951. Protein measurement with the folinphenolreagen. J. Bio. Chem. 193, 265-275.

Lu, Q., Z.L. He, D.A. Graetz, P.J. Stoffella and X.Yang. 2010. Phytoremediation to remove nutrients and improve eutrophic stormwaters using water lettuce (Pistiastratiotes L.) Environ. Sci. Pollut. Res. 17, 84-96.

Masayuki, Y., M. Toshiyuki, K. Akinobu, K. Tadashi and M. Hisashi. 2001. Medicinal flowers. III. Marigold (1): hypoglycemic, gastric emptying inhibitory and gastroprotective principles and new oleanane-type triterpene oligoglycoside, calendasaponins $\mathrm{A}, \mathrm{B}, \mathrm{C}$, and D, from Egyptian Calendula officinalis. Chem. Pharm. Bull, 9, 863-870.

Muller, M. and D. Brandes. 1997. Growth and development of Artemisia annuaL. on different soil types. Verhandlungen der Gesellschaft fur Okologie. 27: 453-460

Nicoletta, C., B. Marongiu, A. Piras, T. Pivetta and S. Procedda. 2003. Extraction, separation, and isolation of volatiles and dyes from Calendula officinalis L. and Aloysiatryphylla (L'Her) britton by supercritical $\mathrm{CO}_{2}$. J. Esse. Oil Res. 15, 272-277.

Prakash, V., H. Bisht, P. Prasad. 2011. Altitudinal variation in morpho-physiological attributes in Plantago major: Selection of suitable cultivation site. Res. J. Med. Plants. 5, 302-311.

Rizhsky, L., H. Liang and R. Mittler. 2002. The combined effect of drought stress and heat shock on gene expression in tobacco. Plant Phys. 130, 1143-1151. 
Savin, R. and M.E. Nicolas. 1996. Effects of short periods of drought and high temperature on grain growth and starch accumulation of two malting barley cultivars. Aust. J. Plant Phys. 23, 201-210.

Shah, N. and G. Paulsen. 2003. Interaction of drought and high temperature on photosynthesis and grain-filling of wheat. Plant and Soil. 257, 219-226.

Singh, V.P., M. Singh, K. Singh, A.A. Naqvi and P. Saini. 2002. Influence of harvest time on the yield and composition of Artemisia annuaessential oil in north Indian plains. J. Medi. Aro. Plant Sci.24(2), 390-392.

Smith, V.M. 2007. Using primary productivity as an index of coastal eutrophication: the unit of measurement matter. J. Plant Res. 3, 29:1-6.

Steel, R.G.D. and J.H. Torrie. 1986. Principles and Procedures of Statistics: A Biometrical Approach (2nd Ed.). McGraw Hill Co. Inc., NY, USA.

Streb, P., W. Shang, J. Feierabend and R. Bligny. 1998. Divergent strategies of photoprotection in high-mountain plants. Planta. 207, 313-324.
Vaidyanathan, H., P. Sivakumar, R. Chakrabarsty and G. Thomas. 2003. Scavenging of reactive oxygen species in NaCl-stressed rice (Oryza sativa L.)-differential response in salt-tolerant and sensitive varieties, Plant Science, 165, 1411-1418.

Velikova, V., I. Yordanov and A. Edreva. 2000. Oxidative stress and some antioxidant systems in acid rain-treated bean plants protective role of exogenous polyamines. Plant Sci. 151(1), 59-66.

Wang, Y., W. He, H. Huang, L. An, D. Wang and F. Zhang. 2009. Antioxidative responses to different altitudes in leaves of alp7ine plant Polygonumviviparum in summer. Acta Phys. Plant. 31, 839-848.

Wang, Z., B. Huang. 2004. Physiological recovery of Kentucky bluegrass from simultaneous drought and heat stress. Crop Sci. 44, 1729-1736.

Wigley, T.M.L., S.C.B. Raper. 2001. Interpretation of high projections for globalmean warming. Sci. 293, 451-454.

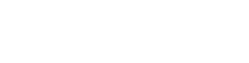 \\ لمتجلبة نمو نبلت الكلانيولا لقالم رجلت الحرارة وأنواع تربةمختلفة}

يلسر ليسماعيل النثار

معل النتح والتوصيل الثغري وتركيز ثاني لمسيد الكربون في الخلايا والمحتوي المائي للخلايا- حيث كانت القيم كبيرة في النباتات المزروعة في الول لكتوبر مع التربة الطينية

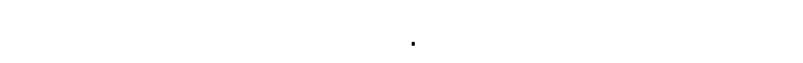

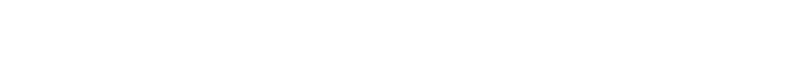
البيوكيميائية المتمثلة في البروتين الذائب الكلي ونشط الفيلة النزيم

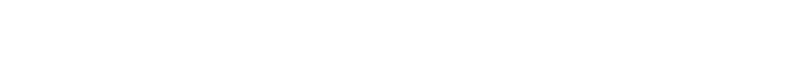

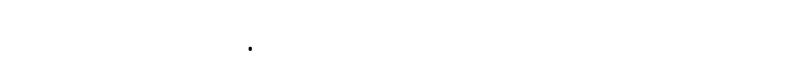
بزراعة نبت الاقحون في المنطق الجلفة وللثبة جلفة خلالشهرسسبتمبر في تربة رملية.

الكامل الفنتاحية: البيئة الجلة والثبة جلهة - المحت وي البيوكيميائية - نبلت الغحولن - التبلال الغ ازي - النم و الاجهاد المائي.
يعتبر الاجهاد الحراري من الظم البيئية الرئيسية التي تؤوثر على الاتناج الزراعي في جمبع النحاء العالم، للاسيما

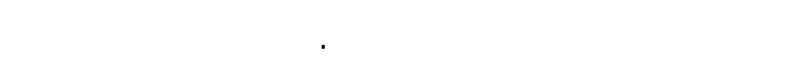
وللشبة جافة بالاختلاف الكبير في الظروف البيئية - فدرجة

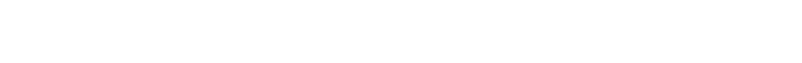

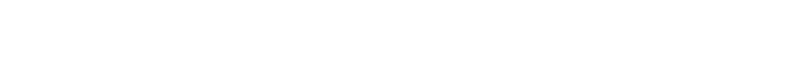

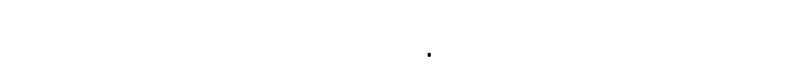
الظم الحرارية على مواعيد زراعة بذور نبلت الاقحوان في

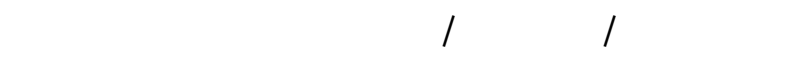

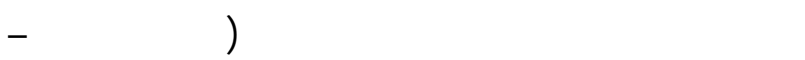
الرملية- الخلط بينهم). وقد لوظ زياة في صفلت النمو الخضري للنباتت المزروعة التربة الرملية مقارنة بالتربة الطينية اللومية والخلط. وقم الحصول على افضل نمو النيال للنباتنا النمية خلال فترة الزراعة 10 سسبتمبر مع التربة التراية الرملية. وتشطل هذه النتائج عدد فروع لكثر ومسلحة ورقة لكبر واثل في الوزن الرطب والجلف وعدد لكبر من الازهار. مُ قيلس عددمن الصفلت الفسيولوجية المتمثلة في 